\title{
A Predictive Determinant of Quality of Life among Homestay Program Participants in Malaysia
}

\author{
Aziz Amin ${ }^{1}$, Ahmad Munir Mohd Salleh ${ }^{2}$, Mohd Shaladdin Muda ${ }^{2} \&$ Yahaya Ibrahim ${ }^{3}$ \\ ${ }^{1}$ Faculty of Social Development, University Malaysia Terengganu, Malaysia \\ ${ }^{2}$ Faculty of Management and Economics, Universiti Malaysia Terengganu, Malaysia \\ ${ }^{3}$ Universiti Sultan Zainal Abidin, Malaysia \\ Correspondence: Ahmad Munir Mohd Salleh, Faculty of Management and Economics, Universiti Malaysia \\ Terengganu, Malaysia. E-mail: munir_salleh@umt.edu.my
}

\author{
Received: February 15, 2012 Accepted: January 14, 2013 Online Published: February 28, 2013 \\ doi:10.5539/ass.v9n3p33 URL: http://dx.doi.org/10.5539/ass.v9n3p33
}

\begin{abstract}
Tourism industry in Malaysia had become very crucial and important in the era of globalization in the $21^{\text {st }}$ century. In Malaysia, tourism is the second largest contributor to the economy after the manufacturing sector. In 2008, the numbers of tourists recorded 22.05 million and tourism had contributed RM49.6 billion (USD13.4 billion) in revenue. Apart from that the total receipts of RM6.3 million had contributed by the homestay program through 68,416 domestic visitors and 23,117 foreign visitors. Therefore the main objective of this study is to identify the predictive determinant of quality of life, government role and attitude that influenced the general well-being amongst the homestay participant. A total of 306 samples was taken from the Homestay Program participants and the data was processed and analyzed using the Statistical Package for Social Science (SPSS). Among the analysis is a reliability test, descriptive and inferential analysis. The growth of the home stay program has provided huge opportunities for the human development. These include positive impact to the rural socioeconomic development, social capital development, as well as increase the quality of life among participants in the homestay program.
\end{abstract}

Keywords: quality of life, well-being, human development

\section{Introduction}

Tourism industry in Malaysia has become more important in the era of globalization in the $21^{\text {st }}$ century. In fact, the tourism sector is the second largest contributor to the economy after the manufacturing sector. In the year 2008, the numbers of tourists recorded were 22.05 million and contributed revenue of RM49.6 billion (USD13.4 billion). The total receipts of RM6.3 million contributed by homestay program came from 68,416 domestic visitors and 23,117 foreign visitors. The concept of the homestay program in Malaysia might be different from others countries. In Australia the term is particularly associated with farmhouse accommodation whereas in the United Kingdom it is associated with learning the English language. According to Lanier and Berman (1993), Homestay program can be described as a private home in which unused rooms are rented for the purposes of supplementing income and meeting people. According to the ministry of tourism, Homestay program is where tourist stays with the host family and experience the everyday way of life of the family in both a direct and indirect manner. Yahaya and Abdul Rasid (2010) claimed that homestay program which is the guests have the opportunities to interact, gain knowledge, and experience the lifestyle and culture of the host family as well as the local community. This element involves the guests eating, cooking, and engaging in many activities together with their adopted families, thus allowing two parties with different cultural backgrounds to interact and learn from each other.

Previous research found that the purpose of homestay in tourism; especially rural homestay is aimed to improve the quality of life (Yusof et al., 2012). A study by Kadir $(1993$; 1995) found that the tourism industry has contributed to the creation of employment opportunities for local residents and can increase their income. While studying by Amran (2003) claims that the Homestay program able to increase self-satisfaction, healthy lives and change participants' socioeconomic level. The growth of homestay program will not only increase revenue and infrastructure facilities but also change the cultural mindset of local communities to realize the importance of 
keeping and preserving cultural heritage to be shared and developed together with the community at the global level (Yahaya et al, 2009). The study by Hall (2001), found that homestay program is also contributing to the care and preservation of the environment through the control of logging activities that may affect the river water pollution.

The objective of the study are to;

1) Determine the level of quality of life attributes and the general well-being amongst the homestay participants

2) Identify the relationship between quality of life attributes and the general well-being amongst the homestay participants

3) Identify the predictive determinant of quality of life, government role and attitude that influenced the general well-being amongst the homestay participant.

\section{Literature Review}

There are many definitions of general well-being, for example, one definition is given as a condition where one feels excited, good and at ease and feels that his/her life is meaningful (Renwick, 2006). Another definition says that it is actually an effort to overcome problems and enhance the quality of one's life until he/she reaches a situation where one's life is safe, healthy and comfortable: physically, socially, and psychologically (Nurdin, 2003). Besides discussing the definitions and the concept of general well-being, the literature also discusses the attributes of quality of life which related to general well-being. Among the variables used in the study relating to the general well-being are income, education, health, housing, transport and communication, peace and safety, family, working environment and social involvement (Pollnac, Pomeroy, \& Harkes, 2001) (Binkley, 2002). Li Liu has carried out a study on general well-being in China and he used five domains of life, namely, health, family, social relationship, occupation and environment as variables (Liu, 2006).

In addition Quality of life has two dimensions to be measured which are objective dimension that is external to the individual and a subjective dimension that reflects to the feelings and perceptions. Cutter (1985) noted that quality of life in the community is comprised of the sum of the objective conditions and individual community feelings about and perceptions of the objective conditions within the community for examples economic, social cultural institution, and environmental conditions. Whereas the subjective of quality of life is about the emotional and value-laden, surrounding factors as life satisfaction, happiness, feelings of well-being, and beliefs about one's standard of living (Davidson \& Cotter,1991; Diener \& Suh,1997; Dissart \& Deller, 2000). Undoubtedly, factors determining the general well-being which usually used by the researchers mentioned above correspond to the factors listed in the Quality of Life Index of Malaysia issued by the Prime Minister's Department, 1999 (UPE, 1999).

From the results of the previous studies show that tourism development has positive effects on quality of life. Liu and Var, (1986) conclude the tourism industry has increased the standard of living in a community with higher income and providing business prospects for them. On the other hand tourism is also affected cultural change and community development. According to Dogan (1989), tourism development has a direct effect on changes in attitudes, beliefs, daily life and the value is likely to cause many problems for human development in a community. According to Lankford and Howard, (1994) those who were directly involved with the tourism industry has a positive attitude than those who are not directly involved.

\section{Methodology}

Based on the review of literatures and the corresponding theoretical perspective, this study has proposed the theoretical model as shown in figure 1. Several variables have been identified which have been used as the hypothesis of the study which is shown in figure 1. A stratified random sampling based on number of participants in the Homestay Program was selected from several locations in Malaysia. According to the Tourism Services Division, Ministry of Tourism, Malaysia, June 2009, the number of participants in the Malaysian Homestay Program is 3,264 people. A total of 306 samples was taken from the Homestay Program participants and the data was processed and analyzed using the Statistical Package for Social Science (SPSS). Among the analysis is a reliability test, descriptive and inferential analysis. 
Table 1. Demografic profiles

\begin{tabular}{|c|c|c|c|}
\hline Demographic Profile & Category & Frequency & Percentage \\
\hline \multirow[t]{2}{*}{ Gender } & Male & 104 & 34.0 \\
\hline & Female & 202 & 66.0 \\
\hline \multirow[t]{6}{*}{ Age } & Below 20 years & 0 & 0.0 \\
\hline & 20 to 29 years & 10 & 3.3 \\
\hline & 30 to 39 years & 24 & 7.8 \\
\hline & 40 to 49 years & 85 & 27.8 \\
\hline & 50 to 59 years & 107 & 35.0 \\
\hline & 60 years and above & 80 & 26.1 \\
\hline \multirow[t]{3}{*}{ Marriage Status } & Single & 18 & 5.9 \\
\hline & Married & 242 & 79.1 \\
\hline & Widower & 46 & 15.0 \\
\hline \multirow[t]{7}{*}{ Education } & Never go to School & 6 & 2.0 \\
\hline & Primary School & 92 & 30.1 \\
\hline & SRP/ PMR (completed form 3) & 54 & 17.6 \\
\hline & SPM (completed form 5) & 120 & 39.2 \\
\hline & STPM & 15 & 4.9 \\
\hline & Diploma & 13 & 4.2 \\
\hline & Degree & 6 & 2.0 \\
\hline \multirow{4}{*}{$\begin{array}{l}\text { Working Length/Period as a participant of } \\
\text { homestay }\end{array}$} & Less than 5 years & 182 & 59.5 \\
\hline & 6 to 10 years & 88 & 28.8 \\
\hline & 11 to 15 years & 32 & 10.5 \\
\hline & 16years and above & 4 & 1.3 \\
\hline \multirow[t]{3}{*}{ Monthly Income* } & RM300 and below & 6 & 2.0 \\
\hline & RM 300 to less than 550 & 19 & 6.2 \\
\hline & RM 550 and above & 281 & 91.8 \\
\hline
\end{tabular}

\subsection{Questionnaires}

The questionnaire consists of three main sections. Section A consists of the demographic factors such as sex, age, marriage status, level of education, period working as a participant of homestay, monthly income, house ownership status, land and transport. Section $\mathbf{B}$ consists of quality of life attributes. They are:

1) Income - the idea is to get a picture of whether the income as a participant of homestay is enough to support the family, to know whether he is satisfied with the income and to make a comparison whether the income now is better than before;

2) Expenditure - to know whether a participant of homestay is satisfied with the expenditure capability for the family, and to see whether he can foresee that his family expenditure in the future will be better than what he has now;

3) Saving - to know whether he has enough saving to use for his family, whether he is satisfied with his saving now, and whether his saving now is better than before;

4) House residence - to know whether the current house that is resided able to accommodate all his family members, whether he is satisfied with his current resided house and also whether his house will be better in the future;

5) Utilities - to know whether the utilities provided are adequate and better than ever before and expecting a better service in future 
6) Land - to know whether the land where he built the house is able to accommodate his family's needs, whether he is satisfied with the land and whether the land will be better or more valuable in the future;

7) Transport - whether he owns any transport and satisfied with the current transport that he owns and whether he hopes that he will own a better transport in the future;

8) Health - to identify whether working as a fisherman can deteriorate his health or it will make him healthier and whether he is satisfied with his current level of health; and

9) Education - to know whether they are satisfied with their current level of education, whether they feel that education is important to improve their standard of living, and whether they agree that better or higher education can improve their standard of living as a participant of homestay.

10) Safety - to know whether the level of security in good condition and guaranteed to improve quality of life

Section C consists of questions to identify the role and responsibilities of the government in an effort to enhance the general well-being of the homestay participant. The role and responsibilities of the government are in:

1) Infrastructure - to know whether the infrastructure provided by the government is adequate, whether they are satisfied and whether the existing infrastructure provided is better compared to before;

2) Course and Training - to find out whether they had ever attended courses or training organized by the government, whether such courses or training being publicized or known by the participant of homestay;

3) Counseling - to know whether the participant of Homestay knows that there is a counseling service provided by the government, whether they are satisfied with the services rendered and also whether the counseling given to them is able to enhance their standard of living;

4) Marketing - is aimed to know whether a participant of homestay are satisfied with the role of the government in stabilizing the price of homestay rental.

5) Enforcement - this is seen whether the enforcement is able to increase the income of the participant of homestay, also to see whether they are satisfied with the level of enforcement and whether they understand matters regarding enforcement;

6) Research and Development for participant of homestay - whether they are aware that there is a research and development for them and whether the results from the research and development of participants of Homestay have given them any benefits.

\section{Findings and Discussions}

\subsection{Demographic Profiles}

The finding shows that 34.0 percent are males and 66.0 percent are female. Based on randomly chosen respondents, it was found that more than 60 per cent of the respondents aged between 40 to 59 years. From the marriage status, it was found that 80 per cent were married. With regard to the education, that is 30.1 percent had completed primary schools and the highest level of education was the completion of the Malaysian Certificate of Education (Sijil Pelajaran Malaysia) schooling, 39.2 percent.

\subsection{Results of Validity and Normality Tests}

The alpha cronbach's values of the factors in the study are as in Table 2. The alpha value for Quality of Life Attributes is 0.958 , government's role is 0.902 , and attitude is 0.937 . The alpha value for dependent variable that is generally well-being is 0.891 . All these alpha values are higher than 0.6 meaning that the factors used in the study are suitable and can be accepted as a measurement (Sekaran, U. 2003). Furthermore normality test for quality of life attributes, government's role, and general well-being shows that the data are normally distributed because the value of skewness and kurtosis is below \pm 3 (Coakes, J. S. and Steed, G. L.,2003).

Table 2. The alpha Cronbach's values

\begin{tabular}{lcc}
\hline Dimensions & No. of Items & Alpha \\
\hline Quality of Life Attributes & 35 & 0.958 \\
Government's Role & 24 & 0.902 \\
Attitude & 8 & 0.937 \\
General well-being & 4 & 0.891 \\
\hline
\end{tabular}




\subsection{Level Quality of Life Attributes, Attitude and General Well-being}

Table 3 show the level quality of life attributes, attitudes and general well-being among the homestay participant. Based on table 3, income, expenditure, saving, land, utilities and infrastructure show the mean between 1.9 to 2.0. Whereas for the attributes such as house, transport, house residence, health, education, safety and research \& development show the mean between 1.5 to 1.8 . On the other hand the level of general well-being is considered low with the mean 1.750 or 43.8 percent. And for the attitude also indicate low mean with 1.593 or 32.2 percent.

Table 3. The mean score of quality of life attributes, attitude and general well-being

\begin{tabular}{lcccc}
\hline \multicolumn{1}{c}{ Determinant Factors } & Minimum & Maximum & Mean & Std. Deviation \\
\hline Income & 1.00 & 4.00 & 1.8791 & .53468 \\
expenditure & 1.00 & 3.67 & 1.9025 & .53445 \\
Saving & 1.00 & 4.00 & 1.9836 & .66013 \\
House & 1.00 & 4.00 & 1.7691 & .46248 \\
Land & 1.00 & 4.00 & 1.8874 & .51164 \\
transport & 1.00 & 4.00 & 1.8377 & .52175 \\
house residence & 1.00 & 4.00 & 1.8492 & .44572 \\
Utilities & 1.00 & 4.00 & 1.8769 & .49745 \\
Health & 1.00 & 4.00 & 1.7625 & .43133 \\
Education & 1.00 & 4.00 & 1.6152 & .44261 \\
Safety & 1.00 & 4.00 & 1.5899 & .44410 \\
Research \& dev & 1.00 & 3.00 & 1.6073 & .39419 \\
Infrastructure & 1.00 & 4.00 & 1.9684 & .51507 \\
Marketing & 1.00 & 3.50 & 1.7998 & .45468 \\
Career counseling & 1.00 & 3.00 & 1.7081 & .41872 \\
Training & 1.00 & 3.00 & 1.7574 & .41309 \\
Policies & 1.00 & 3.00 & 1.7284 & .42180 \\
Enforcement & 1.00 & 3.00 & 1.8039 & .37487 \\
Attitude & 1.00 & 5.00 & 1.5931 & .49341 \\
Well-being & 1.00 & 3.00 & 1.7500 & .48163 \\
\hline & & & & \\
\hline
\end{tabular}

4.3.1 Correlation Analysis between the Determinant Factors of Quality of Life and General Well Being Participant of Program Homestay

The correlation between the determinant factors of quality of life and general well-being is shown in Table 4 . The majority of the attribute dimensions such as income, expenditure, saving, house residence, land, transport and education have significant correlation with the general well-being. All those factors are significant at 0.01 , 2-tailed which shows that the factors are very significant. At the same time all the related factors are positive. Hence, it shows an increase in income, expenditure, saving, residence house, residence land, transport and education will enhance their general well-being. 
Table 4. Correlation analysis between the determinant factors of quality of life and general well being

\begin{tabular}{|c|c|c|c|c|c|c|c|c|c|c|c|c|c|c|c|c|c|c|c|c|}
\hline & $A$ & B & C & $\bar{D}$ & $\mathrm{E}$ & $\mathrm{F}$ & $\mathrm{G}$ & $\vec{H}$ & $T$ & $J$ & $\mathrm{~K}$ & $\mathrm{~L}$ & $\mathrm{M}$ & $\mathrm{N}$ & $\mathrm{O}$ & $P$ & $Q$ & $\mathrm{R}$ & S & $\mathrm{T}$ \\
\hline A & 1 & & & & & & & & & & & & & & & & & & & \\
\hline$B$ & $.792^{\star \star *}$ & 1 & & & & & & & & & & & & & & & & & & \\
\hline C & $.696^{* \star}$ & $.734^{\star \star}$ & 1 & & & & & & & & & & & & & & & & & \\
\hline D & $.659^{\star \star}$ & $629^{*}$ & $615^{\star \star}$ & 1 & 1 & & & & & & & & & & & & & & & \\
\hline E & $442^{* \star}$ & $.563^{\star}$ & $569^{* *}$ & $.682^{\star * \star}$ & 1 & I & & & & & & & & & & & & & & \\
\hline$F$ & $.613^{* \star}$ & $.595^{\star *}$ & $574^{* * *}$ & $.647^{\star \star}$ & $.641^{\star \star}$ & 1 & & & & & & & & & & & & & & \\
\hline G & $.623^{\star \star}$ & $.590^{*}$ & $570^{\star \star *}$ & $.722^{\star \star}$ & $.618^{\star \star}$ & $.644^{\star *}$ & 1 & & & & & & & & & & & & & \\
\hline $\mathrm{H}$ & $.530^{\star \star}$ & $.558^{\star *}$ & $500^{\star \star}$ & $.560^{\star \star \star}$ & $.535^{\star \star}$ & $.506^{\star \star}$ & $.726^{\star}$ & 1 & & & & & & & & & & & & \\
\hline I & $.461^{\star \star *}$ & $.451^{\star}$ & $424^{\star *}$ & $.537^{\star *}$ & $.510^{\star *}$ & $.628^{\star *}$ & $.578^{*}$ & $.508^{\star *}$ & 1 & & & & & & & & & & & \\
\hline $\mathrm{J}$ & $.310^{\star \star}$ & $.304^{*}$ & $187^{\star \star *}$ & $377^{\star \star}$ & $.311^{\star \star}$ & $.373^{\star \star}$ & $.378^{\star}$ & $392^{\star \star}$ & $.534^{\star \star}$ & 1 & & & & & & & & & & \\
\hline K & $.353^{* \star}$ & $.350^{*}$ & $196^{\star \star}$ & $465^{\star *}$ & $.362^{\star \star}$ & $.424^{\star \star}$ & $.436^{*}$ & $359^{* *}$ & $.590^{\star \star}$ & $.730^{\star *}$ & 1 & & & & & & & & & \\
\hline L & $.241^{\star \star}$ & $.216^{\star \star}$ & $205^{\star *}$ & $.299^{\star * *}$ & $279^{* \star}$ & $.282^{\star \star}$ & $.341^{*}$ & $236^{* *}$ & $.344^{\star \star}$ & $.421^{*}$ & $.394^{* *}$ & 1 & & & & & & & & \\
\hline M & $200^{\star *}$ & $.183^{\star *}$ & $185^{\star \star}$ & $.156^{\star \star}$ & $.226^{* *}$ & $.240^{* *}$ & $233^{*}$ & $377^{\star \star}$ & $215^{\star \star}$ & $189^{\star *}$ & $.119^{\star \star \star}$ & $.347^{* i}$ & 1 & & & & & & & \\
\hline $\mathrm{N}$ & -.057 & -.018 & -.027 & $.02 s$ & $127^{\star \star}$ & .003 & .033 & $.124^{\star *}$ & $.115^{\star \star}$ & $137^{\star}$ & $.181^{\star *}$ & $.416^{* 1}$ & $.433^{* *}$ & 1 & & & & & & \\
\hline O & $.101^{\star \star *}$ & $.113^{\star *}$ & .005 & $.228^{\star * *}$ & $.226^{* *}$ & $.148^{\star \star}$ & $.144^{*}$ & $126^{*}$ & $.276^{\star \star}$ & $.334^{*}$ & $.422^{* *}$ & $.404^{* 1}$ & $.266^{* \star}$ & $.466^{\star}$ & 1 & 1 & & & & \\
\hline $\mathrm{P}$ & $101^{\star \star}$ & $.071^{*}$ & -.036 & $.140^{\star \star}$ & $.168^{\star \star}$ & $.147^{\star \star}$ & $.122^{*}$ & $.183^{\star \star}$ & $.229^{\star \star}$ & $211^{\star}$ & $.316^{\star \star}$ & $.270^{*}$ & $267^{\star *}$ & $466^{\star}$ & $501^{\star *}$ & 1 & & & & \\
\hline Q & $.134^{\star \star}$ & $.161^{\star *}$ & $.099^{\star}$ & $.194^{\star \star}$ & $182^{\star \star}$ & $.167^{\star \star}$ & $.136^{*}$ & $.163^{\star \star}$ & $.288^{\star \star}$ & $.338^{\star}$ & $.459^{\star \star \star}$ & $.404^{*}$ & $.251^{\star \star}$ & $.372^{\star *}$ & $658^{\star *}$ & *. $556^{\star \star}$ & 1 & & & \\
\hline$R$ & $.228^{\star \star}$ & $.294^{*}$ & $220^{\star \star \star}$ & $.308^{\star *}$ & $296^{* *}$ & $270^{\star \star}$ & $.218^{*}$ & $235^{\star \star}$ & $.304^{\star \star}$ & $.301^{\star}$ & $.457^{* *}$ & $.350^{* 1}$ & $190^{* *}$ & $.304^{\star *}$ & $571^{\star x}$ & $.469^{\star \star \star}$ & $.698^{*}$ & 1 & & \\
\hline$S$ & $230^{\star \star *}$ & $.196^{*}$ & $173^{\star \star}$ & $.241^{\star \star}$ & $.184^{\star *}$ & $.202^{\star \star}$ & $.237^{\star}$ & $.154^{\star *}$ & $243^{\star \star}$ & $317^{\star *}$ & $253^{\star *}$ & $.374^{* 1}$ & $.092^{* \star}$ & $.158^{\star *}$ & $194^{* *}$ & $202^{\star \star}$ & $.243^{\star *}$ & $: 194^{\star \star}$ & 1 & \\
\hline $\mathrm{T}$ & $.412^{* \star}$ & $.445^{\star}$ & $354^{\star * *}$ & $278^{\star * *}$ & $.333^{* *}$ & $.309^{\star \star}$ & $402^{*}$ & $405^{\star *}$ & $268^{\text {** }}$ & $253^{*}$ & $.183^{* *}$ & $.355^{\star \prime}$ & $.425^{\star}$ & $.187^{\star *}$ & $242^{* x}$ & * $137^{\star \star \star}$ & $169^{\star *}$ & $194^{\star \star}$ & $.310^{\star *}$ & \\
\hline \multicolumn{21}{|c|}{ **. Correlation is significant at the 0.01 level (2-tailed). } \\
\hline${ }^{*}$. & Correlat & tion is : & significe & ant at th & he 0.05 & 5 level ( & (2-taile & & & & & & & & & & & & & \\
\hline
\end{tabular}

\begin{tabular}{lllllllll} 
& \multicolumn{9}{c}{ Legend } & & \\
A & Income & F & Transport & K & Safety & P & Training \\
B & Expenditure & G & House residence & L & Research \& development & Q & Policies \\
C & Saving & H & Utilities & M & Infrastructure & R & Enforcement \\
D & House & I & Health & N & Marketing & S & Attitude \\
E & Land & J & Education & O & Career counseling & T & Wellbeing
\end{tabular}

In summary, relationship between quality of life attributes and the general well-being is low, that is the value of $r$ between 0.137 and 0.445 . For examples the correlation multiplier value of income $(\mathrm{r}=0.412)$, transport $(\mathrm{r}=$ $0 . .309)$, saving $(r=0.354)$, and house residence $(r=0.402)$. Even though it is in the low level but the correlation multiplier value at significant 0.01 which is a strong correlation level. Nevertheless, the relationship is positive which means that an increase in the quality of life and attitude will increase the general well-being.

4.3.2 The Influence of the Determinant Factors of Quality of Life towards the Participant of Homestay Well-being

Regression analysis findings show the influence of independent variables which is the determinant factors of quality of life, the role of the government and attitude of the participant of Homestay satisfaction as in Table 5. The regression analysis for the participant of homestay well-being found that expenditure is the most influential in the relationship between determinant factors of quality of life and participant of homestay because the standard coefficient value beta 0.269 is highest, followed by house $(\beta=-0.212)$. Likewise, for the role of the government dimensions it was found that infrastructure is the most influential $(\beta=0303)$ and attitude show $(\beta=$ $0.170)$. Based on the table 5 the value of $R$ is $0.642, R^{2}$ is 0.412 , adjusted $R^{2}$ is 0.372 . The result of the anova analysis showed the significant mean difference $\mathrm{F}$ is $10.344, \mathrm{p} \quad 0.05$. This means that the determinant factors of quality of life, the role of the government and attitudes have contributed approximately 40 percent of the variance of the well-being among the Homestay participants. The remaining of about 60 percent of the variance of the well-being was influenced by other factors. 
Table 5. The influence of the determining factors of quality of life towards the participant of homestay satisfaction

\begin{tabular}{|c|c|c|c|c|c|c|c|}
\hline \multirow[b]{2}{*}{ Model } & \multicolumn{2}{|c|}{$\begin{array}{l}\text { Unstandardized } \\
\text { Coefficients }\end{array}$} & \multirow{2}{*}{$\begin{array}{c}\begin{array}{c}\text { Standardized } \\
\text { Coefficients }\end{array} \\
\text { Beta }\end{array}$} & \multirow[b]{2}{*}{$\mathrm{t}$} & \multirow[b]{2}{*}{ Sig. } & \multicolumn{2}{|c|}{ Collinearity Statistics } \\
\hline & $\mathrm{B}$ & Std. Error & & & & Tolerance & VIF \\
\hline 1 (Constant) & .131 & .154 & & .850 & .396 & & \\
\hline Income & .101 & .090 & .108 & 1.124 & .262 & .228 & 4.383 \\
\hline expenditure & .243 & .088 & .269 & 2.757 & .006 & .220 & 4.541 \\
\hline Saving & .005 & .059 & .006 & .079 & .937 & .332 & 3.009 \\
\hline House & -.226 & .092 & -.212 & -2.445 & .015 & .278 & 3.601 \\
\hline Land & .094 & .073 & .099 & 1.297 & .196 & .357 & 2.804 \\
\hline transport & -.075 & .068 & -.081 & -1.100 & .272 & .383 & 2.611 \\
\hline house residence & .163 & .095 & .149 & 1.711 & .088 & .275 & 3.633 \\
\hline Utilities & .036 & .077 & .036 & .473 & .637 & .362 & 2.766 \\
\hline Health & -.023 & .079 & -.020 & -.284 & .776 & .417 & 2.401 \\
\hline Education & .062 & .079 & .057 & .783 & .434 & .398 & 2.510 \\
\hline Safety & -.093 & .089 & -.085 & -1.049 & .295 & .317 & 3.159 \\
\hline research and dev & .160 & .075 & .131 & 2.135 & .034 & .555 & 1.803 \\
\hline infrastructure & .286 & .055 & .303 & 5.187 & .000 & .613 & 1.631 \\
\hline Marketing & -.019 & .069 & -.018 & -.277 & .782 & .494 & 2.025 \\
\hline Career counseling & .035 & .082 & .030 & .433 & .665 & .423 & 2.365 \\
\hline Training & -.043 & .073 & -.037 & -.594 & .553 & .542 & 1.845 \\
\hline Policies & -.049 & .086 & -.042 & -.563 & .574 & .371 & 2.696 \\
\hline Enforcement & .048 & .091 & .037 & .526 & .599 & .423 & 2.366 \\
\hline Attitude & .166 & .050 & .170 & 3.288 & .001 & .784 & 1.275 \\
\hline $\mathrm{R}$ & & 2 & Adjust & $\mathrm{R}^{2}$ & & & sig \\
\hline $.642^{\mathrm{a}}$ & & 12 & .37 & & & & .00 \\
\hline
\end{tabular}

\section{Conclusion}

A predictive determinant of quality of life for home stay participants will be developed. The growth of the home stay program has provided huge opportunities for the human development. These include positive impact to the rural socioeconomic development, social capital development, as well as increase the quality of life among participants in the homestay program.

Based on the findings and discussions several conclusions are made. They are:

1) The level of general well-being of the homestay participant in Malaysia is low. For example the level of the general well-being according to the determinant factors with the mean 1.75 . The quality of life attributes for homestay participant is also low with the mean between .193 to .331 . For the role of the government the mean value are between .125 to .390 .

2) In the effort to to improve the level of general well-being of the homestay participant, there are two parties involved directly. They are the participant themselves and the government. Hence, the study has listed factors 
influencing the general well-being according to the quality of life attributes and the role of the government as in table 5 .

3) For the quality of life attributes factors, serious attention should be given to income, education, transport ownership, residence house, saving, expenditure, and residence land foundation. To the role of the government dimensions, attention should be given to course and training, counseling, marketing, research and development and infrastructure.

4) Even though the findings of the study have divided the general well-being according to the quality of life attributes and the role of the government dimensions, both are strongly interrelated. For example, income has positive correlation and significantly to the training, counseling, research and development, marketing, and infrastructure factors. Similarly, education has a positive correlation to the role of the government factors. Therefore, in an effort to improve the general well-being of the homestay, the government should:

a) Increase courses and training programs to the participants taking into consideration the number of courses and training, publicity for the target group, content and method of the course and also always make the performance evaluation of every course done;

b) Increase the counseling effort and make it easier for the homestay participant. This means that increase the number of counseling and venue or centre to get counselled. Through this approached who have problems will find it easier to see the officers involved to get advice. At the time the officers should be on the field dealing directly with the homestay participant by giving the information and advice where ever needed;

c) Increase the research and development program for homestay in various aspects such as materials and equipment, approach, management, economy, marketing and also social and

d) Safeguard the existing infrastructure, improve the quality of the existing infrastructure and increase the number and types of infrastructure so that they are better than before.

\section{References}

Abdullah, A. B. (2004). Persidangan halatuju sektor pertanian dan industri asas tani. Kuala Lumpur.

Binkley, M. (2002). Set Adrift: Fishing Families. University of Toronto Press, Toronto.

Bryman, A., \& Cramer, D. (2001). Quantitative data analysis with SPSS release 10 for windows (1st ed). London: Tylor \& Francis Inc.

Coakes, J. S., \& Steed, G. L. (2003). SPSS Analysis without Anguish Version 11.0 for Windows. John Wiley \& Sons Australia, Ltd.

Davidson, W. B., \& Cotter, P. R. (1991). The relationship between sense of community and subjective well-being: A first look. Journal of Community Psychology, 19, 246-253. http://dx.doi.org/10.1002/1520-6629(199107)19:3<246::AID-JCOP2290190308>3.0.CO;2-L

Diener, E., \& Suh, E. (1997). Measuring quality of life: Economic, social, and subjective indicators. Social Indicators Research, 40, 189-216. http://dx.doi.org/10.1023/A:1006859511756

Dissart, J. C., \& Deller, S. C. (2000). Quality of life in the planning literature. Journal of Planning Literature, 15(1), 135-161. http://dx.doi.org/10.1177/08854120022092962

Dogan, H. (1989). Forms of adjustment: Socio-cultural impacts of tourism. Annals of Tourism Research, 16, 216-236. http://dx.doi.org/10.1016/0160-7383(89)90069-8

Field, A. (2003). Discovering statistics using SPSS for windows (1st ed.). London: Sage Publication.

Fox, K. S. (1974). Social Indicators and Social Theory: Elements of an Operational System. New York: Wiley.

Hair, J. E., Anderson, R. E., Tathan, R. L., \& Black, W. C. (1998). Multivariate data analysis (5th ed.). New Jersey: Prentice-Hall International, Inc.

Hamzah, A., \& Ismail, H. N. (2003). An assessment of the social-economic impact of the Homestay Program at Kampung Banghuris, Sepang, Selangor. Short Term Research Grant. Research Management Centre, UTM.

Ibrahim, Y., \& Razzaq, A. R. A. (2009). Homestay Program and Rural Community Development in Malaysia. International Workshop on Production Process of Tourism S and Interface among Local Residents, Foreign Tourists and Foreign Workers. Comparative Studies on Asian Countries.

Kadir, H. D. (1993). Dialogue with the Hosts: An Educational Strategy Sustainable Tourism. In V. T. King, M. 
Hitchcock, \& M. J. G. Parnwell (Eds.), Tourism in South-East Asia. London: Routledge.

Kadir, H. D. (1995). Entertaining guest in remote areas: benefit and problems. Kertas Seminar Kebangsaan Dampak Perluasan Pasaran ke atas Komuniti Setempat, UKM, Cawangan Sabah.

Lankford, S. V., \& Howard, D. R. (1994). Developing a tourism impact attitude scale. Annals of Tourism Research, 21(1), 121-139. http://dx.doi.org/10.1016/0160-7383(94)90008-6

Liu, B. C. (1975). Quality of Life: Concept, Measure and Results. The American Journal of Economics and Sociology, 34(1), 1-14. http://dx.doi.org/10.1111/j.1536-7150.1975.tb01151.x

Liu, J. C., \& Var, T. (1986). Resident attitudes towards tourism impacts in Hawaii. Annals of Tourism Research, 13, 193-214. http://dx.doi.org/10.1016/0160-7383(86)90037-X

Liu, L. (2006). Quality of Life as a Social Representation in China: A Qualitative Study. Social Indicators Research, 75(2), 217-240. http://dx.doi.org/10.1007/s11205-004-3198-z

Nurdin, M. F. (2003). Penilaian Dampak Pembangunan Ke Arah Kesejahteraan Masyarakat, Penilaian Dampak Sosial. Utusan Publication \& Distributor Sdn.Bhd. Kuala Lumpur.

Pollnac, R. B., Pomeroy, R. S., \& Harkes, I. H. T. (2001). Fishery Policy and Job Satisfaction in Three Southeast Asian Fisheries. Ocean and Coastal Management, 44, 531-544. http://dx.doi.org/10.1016/S0964-5691(01)00064-3

Renwick, R. (2006). The Quality Life Model. Retrieved from http://www.utoronto.ca/qol/concepts.htm

Sekaran, U. (2003). Research Method For Business: A Skill Building Approach (4th ed.). John Willey \& Sons, Inc. New York.

UPE. (1999). Usaha Ke Arah Peningkatan Kualiti Hidup, Kualiti Hidup Malaysia 99. Jabatan Perdana Menteri Malaysia, Percetakan Nasional Berhad, Kuala Lumpur.

Yassin, M. M., \& Dato, T. S. (2004). Ucaputama YB Menteri Pertanian Dan Industri Asas Tani, Persidangan Halatuju Sektor Pertanian Dan Industri Berasaskan Pertanian. Retrieved from http://agrolink.moa.my/darimejamenteri/exco\%20pertanianpada31/12/2005

Yusof, Y., Ibrahim, Y., Muda, M. S., \& Amin, W. A. A. W. M. (2012). Community Based Tourism and Quality of Life. Review of Integrative Business and Economics Research, 1(1). 